\title{
Mapping the pork value chain in Vietnam: a systematic review
}

\author{
Man Nguyen Thi Thuy ${ }^{1,2,3} \cdot$ Pierre Dorny ${ }^{2,3} \cdot$ Philippe Lebailly $^{4} \cdot$ Chau Le Thi Minh ${ }^{5} \cdot$ Huyen Nguyen Thi Thu ${ }^{6}$. \\ Veronique Dermauw ${ }^{2}$ (1)
}

Received: 16 November 2019 / Accepted: 17 June 2020

(C) Springer Nature B.V. 2020

\begin{abstract}
In Vietnam, pork is the most commonly consumed type of meat, and the demand is expected to rise even further. Nevertheless, food safety is a major concern, as the country bears a high burden of food-borne diseases, including these caused by pork products. Knowledge of the flows of pigs and pork from producers up to the consumers is important; however, up to now, a comprehensive overview is lacking. We addressed this by conducting a systematic review on the pork value chain (PVC) mapping for the country. Four international and three Vietnamese databases were searched for data on the pork value chain in Vietnam, and the results were reported according to the PRISMA guidelines. Data obtained from the retained records showed that 10 main PVC types are present in Vietnam, comprising of five main actors including: producers, middlemen, slaughter men, retailers and consumers. Among the identified chains, the one involving producers, slaughter men, retailers and consumers is the most common one, with up to $75 \%$ of pork following this route. In cities or export routes to other countries, middlemen and/or traders are important additional actors in the PVCs. The small scale of PVC linkages is prominent. The presence of middlemen, pig traders and pork traders is contributing to further distribution of pork products in geographical terms. Transactions between actors in the traditional PVCs in Vietnam are characterized by the absence of official contracts; therefore, the linkages in the chains are loose and the origin of pork is not traceable. More industrial forms of PVCs are slowly developing; however, the traditional PVCs are still prevailing in Vietnam. The weak linkages between actors and poor hygienic practices in these chains form a risk to pork safety.
\end{abstract}

Keywords Pig $\cdot$ Pork value chain $\cdot$ Traceability $\cdot$ Food safety $\cdot$ Vietnam $\cdot$ Review

Electronic supplementary material The online version of this article (https://doi.org/10.1007/s11250-020-02338-y) contains supplementary material, which is available to authorized users.

\author{
Veronique Dermauw \\ vdermauw@itg.be \\ Man Nguyen Thi Thuy \\ nttman1984@gmail.com \\ Pierre Dorny \\ pdorny@itg.be \\ Philippe Lebailly \\ philippe.lebailly@uliege.be \\ Chau Le Thi Minh \\ ltmchau@vnua.edu.vn \\ Huyen Nguyen Thi Thu \\ huyenquyet2002@gmail.com
}

1 National Center for Veterinary Diagnosis, No 11/78 Giai Phong, Phuong Mai, Dong Da, Hanoi, Vietnam

2 Department of Biomedical Sciences, Institute of Tropical Medicine, Nationalestraat 155, 2000 Antwerp, Belgium

3 Faculty of Veterinary Medicine, Ghent University, Salisburylaan 133, 9820 Merelbeke, Belgium

4 Economy and Rural Development Department, University of Gembloux, Gembloux, Belgium

5 Faculty of Accounting and Business Management, Vietnam National University of Agriculture, Trau Quy, Hanoi, Vietnam

6 Faculty of Economics and Rural development, Vietnam National University of Agriculture, Trau Quy, Hanoi, Vietnam 


\begin{tabular}{|c|c|}
\hline \multicolumn{2}{|c|}{ Abbreviations } \\
\hline FAOSTAT & Food and Agriculture data \\
\hline OEDC & $\begin{array}{l}\text { Organization for Economic Co-operation and } \\
\text { Development }\end{array}$ \\
\hline $\mathrm{PVC}$ & Pork value chain \\
\hline PRISMA & $\begin{array}{l}\text { Preferred Reporting Items for Systematic re- } \\
\text { views and Meta-Analyses }\end{array}$ \\
\hline STD & Vietnamese Science and Technology database \\
\hline WHO & World Health Organization \\
\hline
\end{tabular}

\section{Introduction}

Pork is the most popular type of meat in Vietnam, accounting for around $73 \%$ of meat consumption (Nguyen et al. 2006). A steady growth of per capita pork consumption was observed in the country, rising from $8.1 \mathrm{~kg} / \mathrm{capita} /$ year in 1990 to $31.3 \mathrm{~kg} /$ capita/year in 2018 (OEDC 2018). During the same time period, the number of pigs has increased from 12 million to more than 27 million (FAOSTAT 2019). In 2018, pork production amounted to 3.8 million tons, an increase of $2.2 \%$ compared with 2017 (Vietnam Livestock Production 2018). Due to the increased domestic demand and the context of globalization, the Vietnamese government has set the objective to increase the pig population to 34 million heads in order to achieve a production of 4.8-4.9 million tons of pork by 2020 (Hoang 2012). Nowadays, family-owned small-scale pig farms are still predominant (Lapar et al. 2012); these are estimated to account for at least $80 \%$ of the total pork production and provide about $14 \%$ of the household income of farmers (Lapar et al. 2012; Nga et al. 2014; Nga 2016).

Food-related health hazards and microbial hazards in particular (e.g. Streptococcus suis, Salmonella spp., Taenia spp., Trichinella spp., etc.) are a great concern in Vietnam (DangXuan et al. 2015a, b, 2019; Ng-Nguyen et al. 2017; World Bank 2017; Yokozawa 2014). Over 5000 people are reported to suffer from food-borne illnesses every year (Vietnam Ministry of Health and Health Partnership Group 2016), although this number could probably be an underestimate due to a low level of reporting. There are 15,537 pig slaughterhouses and slaughter slabs in the country (Nga 2016). In Hanoi, an estimated $61 \%$ of pig production is supplied through familyrun slaughterhouses with a capacity of $1-5$ pigs slaughtered per day (World Bank 2017). Most of these small-scale slaughterhouses do not practice meat inspection (Nga 2016). Consumers buy fresh pork and offal in traditional open/wet markets (Nga et al. 2014) where hygiene is poor and microbial contamination is rife (Dang-Xuan et al. 2015b). Moreover, in Vietnam, certain culinary habits exist which entail consumption of raw pork, e.g. nem chua or thit chua (raw or uncooked pork meat, fermented meat) and tiet canh (uncooked blood mixed with boiled meat and visceral organs), increasing the risk of zoonotic diseases for the consumer (Dang-Xuan et al. 2015a, b; Ng-Nguyen et al. 2017).

Despite the growing concerns over food safety, traceability of pigs and pork is low; consumers thus often do not know the origin of the pork (Nga 2016). The design and implementation of traceable supply chains from farm to consumer have become important items in the overall food quality assurance system (Opara 2003). Acquiring knowledge of the structure and the dynamics of the sequence of related business activities starting from the pig production to processing, marketing and up to the final sale of pork to consumers is a preliminary step to evaluate traceability and food safety. Mapping the pork value chain (PVC) entails identifying and describing the actors that are linked in the chain of production, marketing and transformation activities that move pigs from the farm to pork to consumers. Despite the importance of mapping the PVC for traceability in the Vietnamese context, up to now, a comprehensive overview of the PVCs in the country is not available. The aim of the current paper is, therefore, to review the current knowledge on flows of pigs and pork products from producers up to consumers and actors involved in the process, their functions and marketing relationships to map the PVCs in Vietnam.

\section{Materials and methods}

\section{Search strategy and selection criteria}

A systematic review of published literature was conducted to collect data on flows of pigs and pork products from producers up to consumers and actors involved in the process, their functions and marketing relationships. The scientific databases PubMed, Web of Science, CABI and AGRIS were searched using the following keywords and Boolean operators: (pig OR pork) AND (value chain OR supply chain OR market OR production) AND Vietnam. The Vietnamese databases STD (Vietnamese Science and Technology database), Journal of Agriculture and Rural Development and the National library of Vietnam were also searched for relevant articles using the keywords thit lơn (pork). The review included studies in English and Vietnamese language published between 1990 and December 2018. After collection of data from different databases, duplicate records were removed. Titles and abstracts were screened for relevance. All studies mapping the $\mathrm{PVC}$ in a certain region, describing one of the actors in the chain or presenting data on the quantitative and qualitative aspects of the chain, were included. Full-text records were evaluated and rejected based on the following exclusion criteria: (i) studies presenting data out of the scope of the research question (e.g. studies on meat quality, carcass traits, subsidies, prices), (ii) duplicated records, (iii) studies 
performed outside the study area and (iv) studies published outside the study period. Remaining full-text records were included in a qualitative and quantitative synthesis. Reference lists of included articles were screened for additional relevant records. After record retrieval from the databases, experts at the Vietnamese Department of Animal Health and Vietnam University of Agriculture were consulted to gather grey data on the PVC. The PRISMA guidelines were followed for reporting study results (Moher et al. 2009) (for PRISMA checklist, see Supplemental material 1).

\section{Study variables and data analysis}

Titles, author names and year of publication were collected from every included record. Furthermore, information on the study site, sample size, study period, study method, actors (i.e. characteristics, activities and marketing relationships) and the flow of pigs and pork between actors (i.e. percentages) were gathered. In the context of the current study, the term 'middlemen' is referring to people buying pigs from pig producers, whereas the term 'pig traders' is referring to people buying pigs from middlemen, both middlemen and traders buy to resell them to slaughter men or export to abroad; the term 'pork traders' is referring to people buying pig carcasses and reselling them to retailers. The term 'processors' is used to refer to people who purchase pork and offal and process it to products sold to consumers, while the term 'organizations' was used for schools, canteens of companies and hotels that purchase pork for cooking and serving to consumers. In case records combined flow data on different PVCs (i.e. not differentiating chain types, only different actors), the proportion of pigs/pork products for each of the PVCs was calculated using MS Excel 2013. Wherever described in the selected records, information about food safety was also included in the qualitative analysis.

\section{Results}

\section{Screening process}

A total of 448 records were initially retrieved (Fig. 1), and after checking for duplicates, the title and abstract of 384 records were screened for relevance. Three records and two personal communications were included as additional data sources. Full texts of 46 records were evaluated, after which 29 records were excluded. Finally, 19 records were retained for the qualitative analysis, including 12 articles, one $\mathrm{PhD}$ thesis, three reports, one conference paper (Table 1) and two personal communications for grey data.
Mapping the PVC and flow of pig products in Vietnam

Seventeen selected records had performed a PVC mapping, describing pig and pork flows from farm up to consumers in 30 provinces and cities, mostly in northern and central Vietnam (Figs. 2 and 3). A total of 10 different PVCs (types 1-10) were identified in the retained records, and the proportions of pig product flows following types 1 to 5 were found to be different between provinces (Table 2).

The simplest chain described consisted of two actors: producers and consumers (type 1) (Unger et al. 2018; Lemke et al. 2006). Live pigs are purchased directly from the farms, slaughtered and processed by the consumers. This chain type ensures a low price for consumers and is typically followed for special occasions, e.g. for worshipping ancestors, New Year's day, wedding party and for the trade of special indigenous breeds (Lemke et al. 2006). Another chain (type 2) involves producers, slaughter men and consumers (Thuan et al. 2000; Peters et al. 2005; Baudon et al. 2015; Hoa 2014; Huong 2012; Tan and Hung 2013; Unger et al. 2018). The finishing pigs are sold to slaughter men who will slaughter the pigs, process the carcasses and sell the pork and offal to consumers. The most common chain (type 3) comprises of four actors: producers, slaughter men, retailers and consumers (Thuan et al. 2000; Huong 2012; Tan and Hung 2013; Hoa 2014; Unger et al. 2018). In this chain, live pigs are purchased from farmers and are then slaughtered by slaughter men, who will sell the carcasses to retailers for processing before the meat and offal are sold to consumers.

In chain type 4, consisting of producers, middlemen, slaughter men, retailers and consumers, the pigs are bought by middlemen and then sold to slaughter men for slaughtering. The remaining part of the chain is similar to type 3 (Thuan et al. 2000; Huong 2012; Tan and Hung 2013; Hoa 2014; Unger et al. 2018). Pig and pork traders take part in the most complex chain (type 5), consisting of producers, middlemen, pig traders, slaughter men, pork traders, retailers, processors and consumers (Thuan et al. 2000; Huong 2012; Tan and Hung 2013; Hoa 2014; World Bank 2017). Some variations of type 5 exist, in which one or two actors might be absent. Moreover, in Ho Chi Minh City, $72 \%$ of pork processed in large slaughterhouses were sold to wholesalers and from there generated $20 \%$ of the total pork supply to supermarkets and stores with the rest of the pork being supplied to retailers (World Bank 2017).

Apart from these common PVCs, five other PVCs are described in the included records. One type of PVC is a semiintegrated one, where enterprises supply feed, piglets and veterinary services to the pig producers and buy all finishing pigs to slaughter or sell to slaughterhouses (type 6). These pig products can be processed into food ready for selling to supermarkets, convenience stores or open markets. This chain type is estimated to supply around 5\% and $14-20 \%$ of pork 


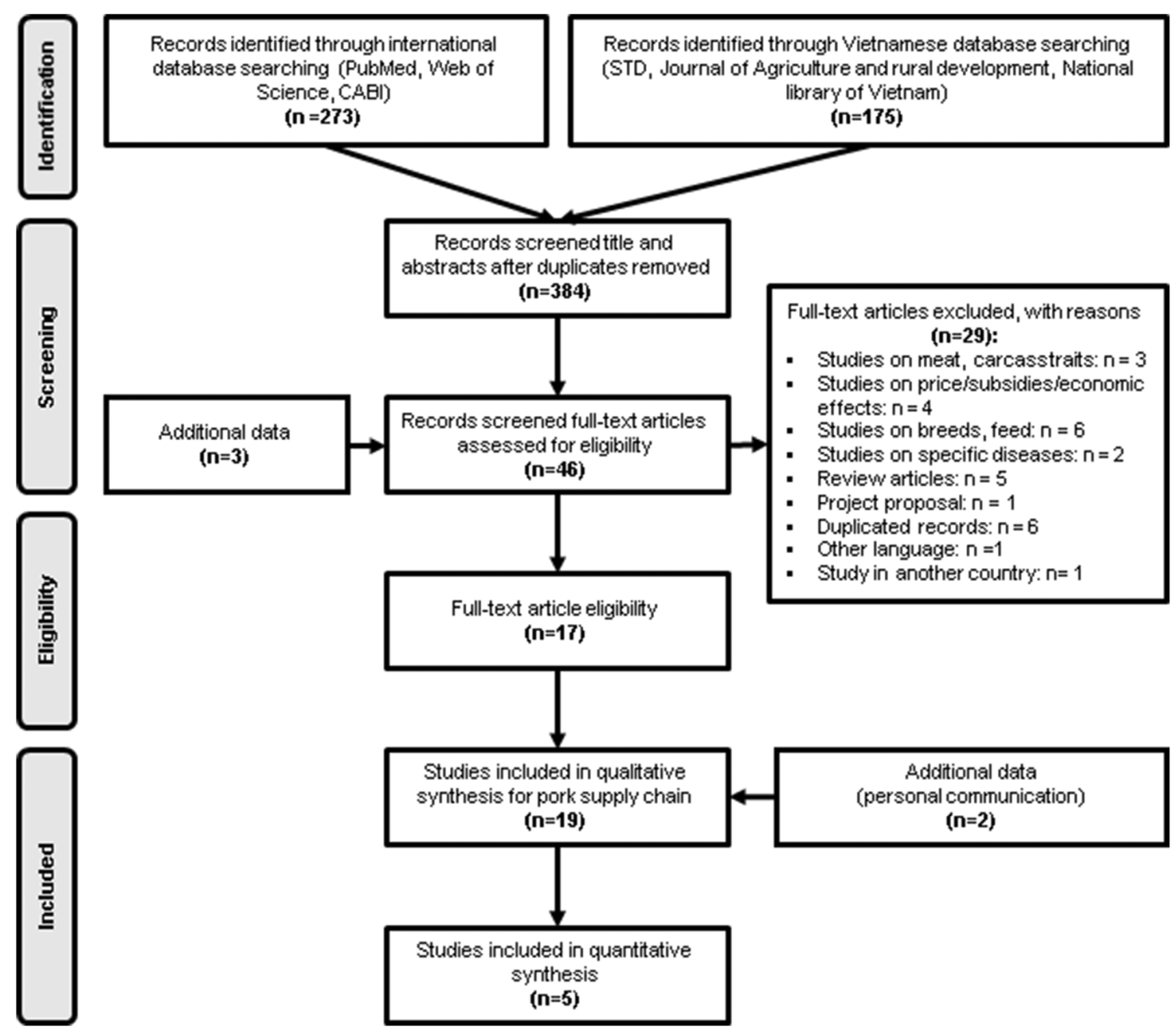

Fig. 1 Flow diagram of the study selection

demand to consumers in Hanoi and Ho Chi Minh City (World Bank 2017). In type 7, few small companies exert full control on the chain from pig producers up to consumers, thus including all steps of the PVC, the vertical integration model (Huyen, personal communication, 2018). In the local breed PVC (type 8), farmers sell pigs of the Ban breed (an indigenous breed originating from mountain areas) to middlemen who resell most of them to consumers and restaurants (Lemke et al. 2006; Huong et al. 2009; Huyen et al. 2016). In the import chain (type 9), pork, offal, skin and other products are supplied to pork traders, retailers, supermarkets, processors and restaurants by import companies purchasing these products in the USA, Australia, Canada, Belgium, France, Russia, Spain and neighbouring countries (Department of Animal Health, personal communication, 2018). In the export chain (type 10), live pigs are gathered by middlemen and sold to pig traders for exporting to China or to slaughter enterprises (export companies) for slaughtering and exporting carcasses to Russia, Hong Kong, Malaysia and Taiwan (Thuan et al. 2000; Department of Agriculture and Forest 2003; Hoa 2014; Unger et al. 2018). In Nam Dinh province, slaughter enterprises exported $62 \%$ of pork products and the rest were sold to consumers directly and to retailers (Thuan et al. 2000).

\section{Characterization of PVC actors}

\section{Pig producers}

Pig production systems in Vietnam range from smallholder farms over semi-industrial farms to industrial farms. Smallholder farms owned by individual farmers typically grow and finish 4-10 pigs per year, while semi-industrial farms, often operated by families, usually rear between 10 and 300 pigs per year, both supplying around $80 \%$ of pig products. The industrial farms rear over $>300$ pigs/year and are operated by state-owned enterprises and joint stock companies (Baudon et al. 2015; Chau et al. 2017; Department of Agriculture and Forest 2003; Peters et al. 2005; Tu et al. 2010; Unger et al. 2018). In PVC type 6, the industrial pig producers make use of formal contracts to organize both the purchase of input supply and the sales of finishing pigs (Huyen, personal communication, 2018). In all chains, apart from PVC type 6, 


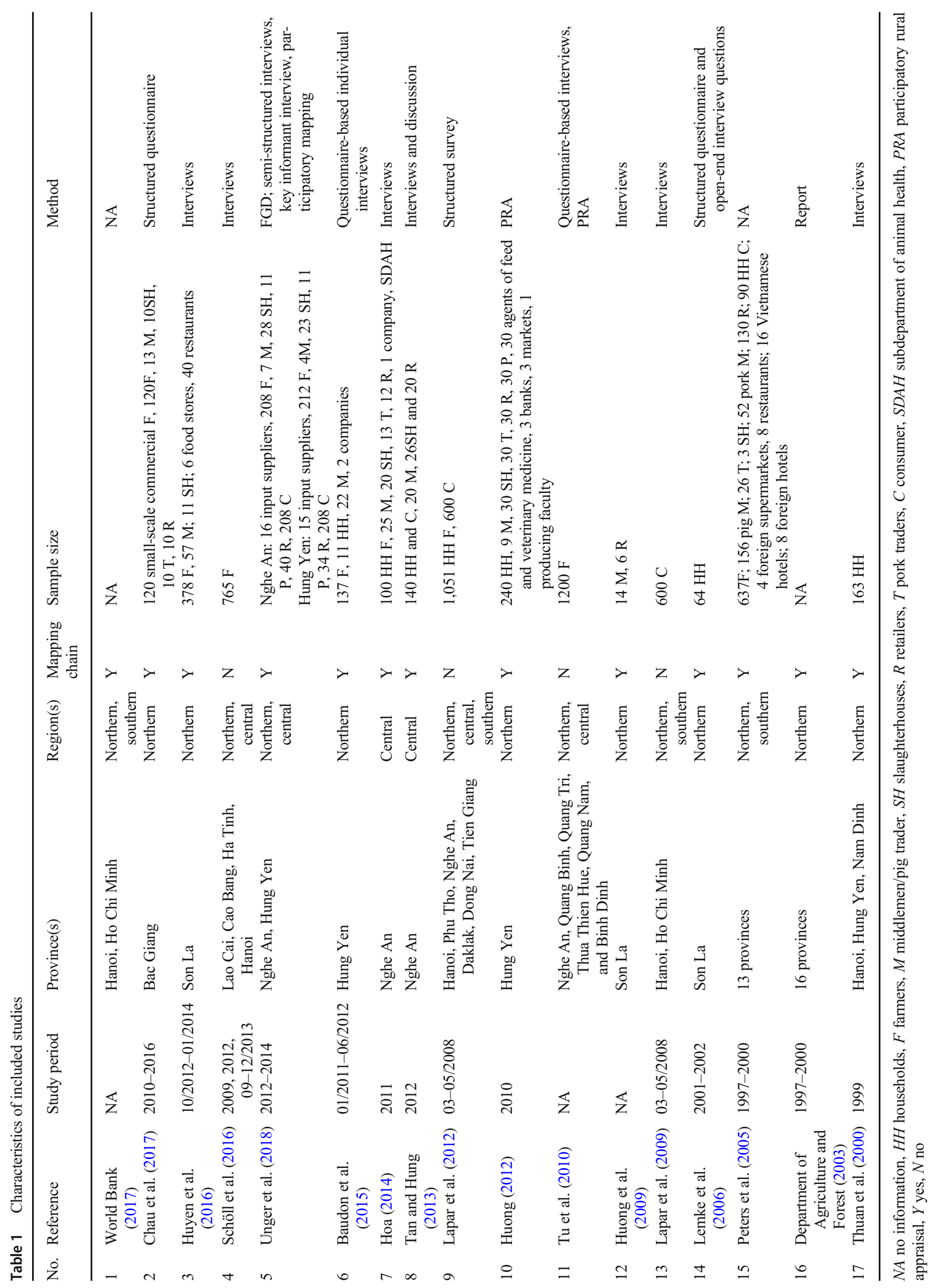


Fig. 2 Retrieved pork value chain studies by province (numbers between brackets refer to study numbers presented in Table 1)

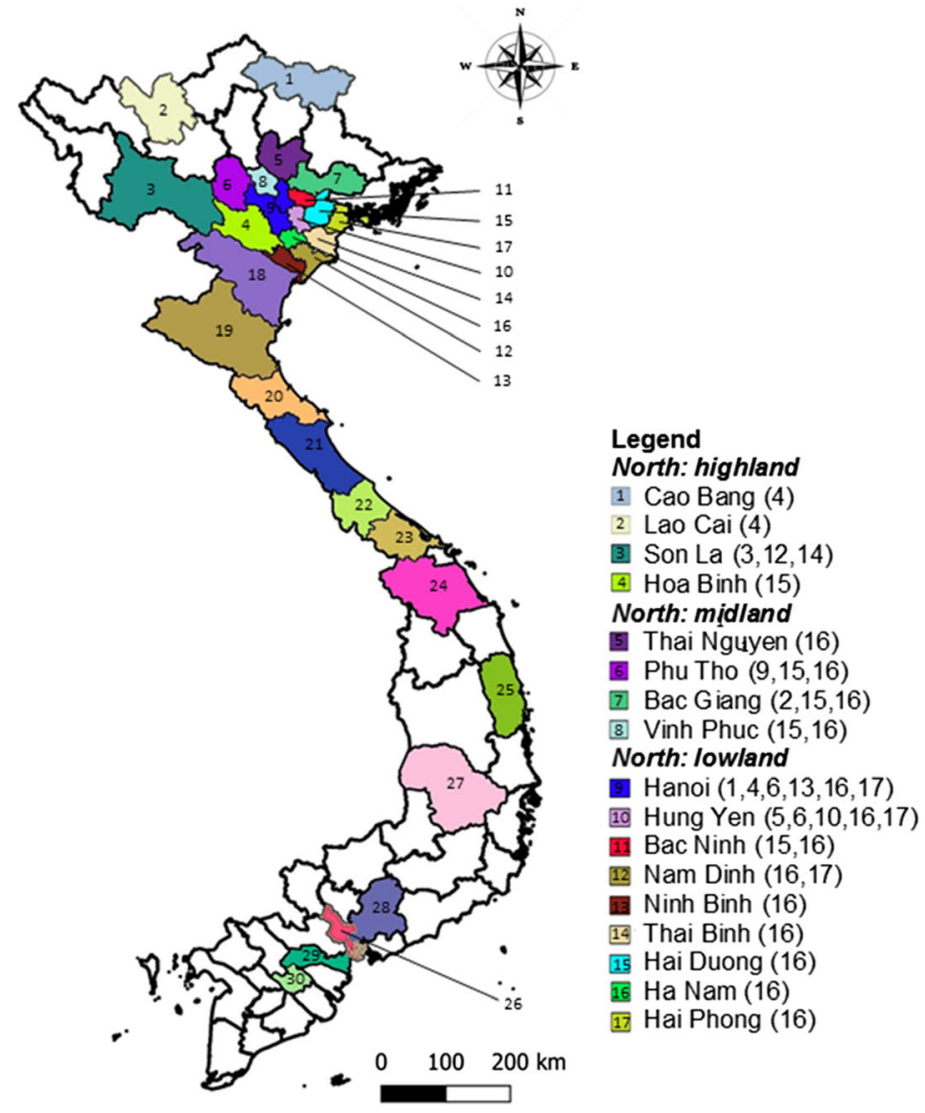

\author{
Central \\ 18 Thanh Hoa $(15,16)$ \\ 19. Nghe An $(5,7,8,9,11,16)$ \\ $20 \mathrm{HaTinh}$ (4) \\ 2 Quang Binh (11) \\ 22 Quang Tri (11) \\ 23 Thua Thien Hue (11) \\ 24 Quang Nam (11) \\ 25 Binh Dinh (11) \\ South \\ 26 Ho Chi Minh $(1,13)$ \\ 27. Dak Lak (9) \\ 28. Dong Nai $(9,15)$ \\ 29. Tien Giang (9) \\ 30 Vinh Long (15)
}

either piglets are purchased from other farmers or producers keep their own sows and raise some of the piglets (Department of Agriculture and Forest 2003; Lemke et al. 2006; Huong 2012; Tan and Hung 2013; Baudon et al. 2015; Huyen et al. 2016; Unger et al. 2018). Commercial feeds account for $67 \%$ of the total feed supply, whereas the smallholders typically feed their pigs with crop residues, leftovers from food shops and restaurants and other feed components mixed with their own feed ingredients (Department of Agriculture and Forest 2003; Peters et al. 2005; Lemke et al. 2006; Huong 2012; Unger et al. 2018). In the Ban breed chain (PVC type 8), piglets are raised in a traditional feeding system (i.e. free scavenging, no commercial feed) (Huyen et al. 2016). Apart from piglets and feedstuff, pig producers buy vaccines and antibiotics and receive technical recommendations from specialized veterinary companies. Except for PVC type 6, no written contracts exist for the transactions between pig producers and these suppliers.

\section{Pig middlemen and traders}

Middlemen gather pigs from various farms and then sell these to slaughterhouses (Chau et al. 2017). Middlemen and traders play a huge role in setting the pig price and delivering pigs to neighbouring districts and provinces (Tan and Hung 2013; Schöll et al. 2016; Chau et al. 2017) for slaughtering and export, thus expanding the supply chain over a larger geographical area (Hoa 2014; Schöll et al. 2016). Transactions between middlemen, pig producers, traders and slaughter men are usually done by cash transfers, and most of them are based on verbal agreements (Tan and Hung 2013; Chau et al. 2017).

\section{Slaughterhouses}

Slaughterhouses in Vietnam are classified into three types, namely, small-scale slaughterhouse, the multiplecompartment slaughterhouse and the semi-industrial slaughterhouse (World Bank 2017). Small-scale slaughterhouses are mainly operated by families whereby pigs are purchased from the producers and slaughtered. Usually five pigs per day are slaughtered in rural areas while less that ten in the cities (Tan and Hung 2013; Chau et al. 2017). Slaughter men directly sell pork and offal to consumers and retailers. Multiplecompartment slaughterhouses purchase pigs from middlemen or semi-commercial farms and sell to pork traders, retailers, processors and other organizations. Semi-industrial slaughterhouses are operated by big companies and supply pigs through the type 5 and type 6 chains. These slaughterhouses sell pork and offal to pork traders, convenient stores, supermarkets and processing factories and also for exportation (World Bank 2017; Huyen, personal communication, 2018). 


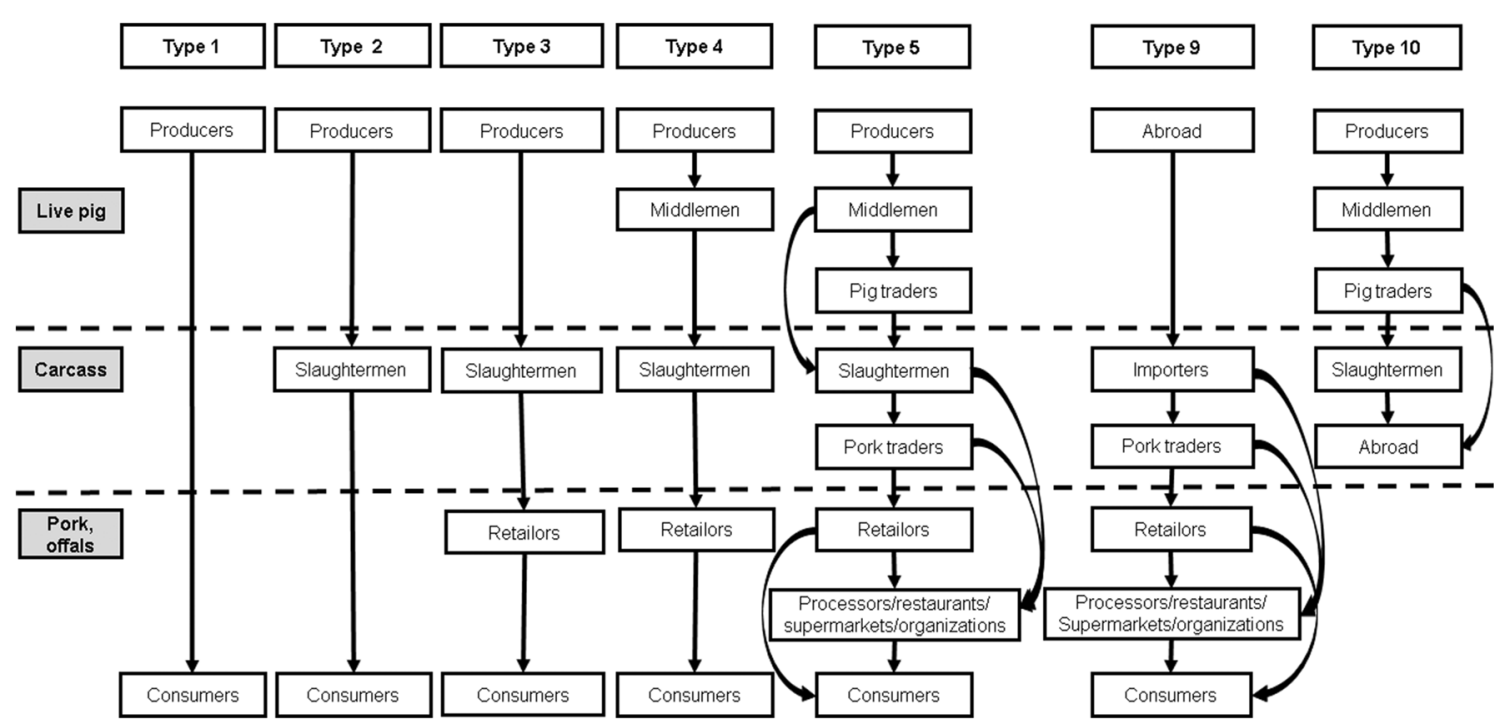

Fig. 3 Traditional pork value chain types in Vietnam

In rural areas, family-run slaughterhouses are common, with explicit task division for each gender: men often slaughter the pigs, while women sell pork at wet markets (Huong 2012; Tan and Hung 2013; BaudoNgan et al. 2015; Unger et al. 2018). In these slaughterhouses, pigs are usually slaughtered on a concrete floor in poor hygienic conditions (Unger et al. 2018; Chau et al. 2017). Some men slaughter pigs at the farms, whereas others kill pigs close to their houses without separating barn, slaughtering and offal processing places (Unger et al. 2018). Carcasses are often sold to retailers; however, blood and organs are sold directly to consumers (Huong 2012).

\section{Pork traders and retailers}

Retailers and traders purchase carcasses from slaughter men and then divide these into smaller pork parts. Pork traders operate in a large geographical area and form the connection between slaughter men and retailers (Thuan et al. 2000).
Among pork traders are also companies importing pork and offal in PVC type 9. Retailers can buy the pork directly from slaughterhouses $(68.0 \%)$ or through pork traders $(26.1 \%)$ and typically sell between half a carcass up to two carcasses per day (Thuan et al. 2000; Huong 2012; Tan and Hung 2013; Chau et al. 2017). Over $95 \%$ of retailers sell fresh pork at the wet market and present the carcasses on tables without covering and packing (Unger et al. 2018).

\section{Consumers}

Consumers often purchase pork and offal from acquaintance retailers as they consider their products safe for consumption and the price reasonable (Unger et al. 2018). Vietnamese consume most parts of the pigs such as meat, feet, ear, the head including the brain and offal. Each year, consumers' demand increases around January and February when preparing for the Tet celebration (Lunar New Year) (Huyen et al. 2016). The

Table 2 Proportion of pig products following each chain in several Vietnamese provinces

\begin{tabular}{|c|c|c|c|c|c|c|c|}
\hline \multirow[t]{2}{*}{ Province } & \multicolumn{6}{|l|}{ Chain } & \multirow[b]{2}{*}{ Reference } \\
\hline & Type $1(\%)$ & Type $2(\%)$ & Type $3(\%)$ & Type $4(\%)$ & Type $5(\%)$ & $\begin{array}{l}\text { Other chains } \\
(\%)\end{array}$ & \\
\hline Nghe An, Hung Yen & 2.6 & 17.4 & 36.2 & & 2.2 & $41.6^{*}$ & Unger et al. (2018) \\
\hline Nghe An & & 38.3 & 11.2 & 0.04 & 1.2 & $49.1 * *$ & Hoa (2014) \\
\hline Nghe An & & & 60.3 & 19.7 & 20.0 & & Tan and Hung (2013) \\
\hline Hung Yen & & & 75.0 & & 25.0 & & Huong (2012) \\
\hline Hung Yen & & 7.0 & 49.3 & 28.7 & 14.9 & & Thuan et al. (2000) \\
\hline Hanoi & & 29.4 & 54.5 & 1.9 & 14.1 & & Thuan et al. (2000) \\
\hline
\end{tabular}

* export chain to other provinces

**producer, processing food company and export chain to China and other provinces 
majority of consumers prefer to buy their pork for home consumption at permanent retail markets and traditional temporary outlets rather than at modern outlets such as supermarkets (Lapar et al. 2009; Chau et al. 2017). Consumers have a strong preference for daily fresh pork; however, the changing demand to cold meat increases due to concerns about food safety (Lapar et al. 2009, 2012; Chau et al. 2017).

\section{Other actors: processors, restaurants, food stores and organizations}

Traditional processors buy pork and offal from slaughter men, pork traders and retailers to process for traditional food such as sausage (gio), cha, ruoc and boiled intestine and sell it at traditional markets (Huong 2012). Food companies are supplied with pork from their own chain (type 6) or from slaughterhouses or pig traders. Their products are sold in food stores, convenient stores and supermarkets and supplied to organizations such as schools and canteens (Huyen, personal communication, 2018). Restaurants, food stores and organizations can purchase pork and offal from the slaughter men or pork traders for food preparation (World Bank 2017). Some restaurants and food stores in Hanoi are also involved in the Ban PVC (type 8), with this type of pork being supplied from highland areas, e.g. Son La province (Huyen et al. 2016).

\section{Discussion}

The results of this study revealed a diversity of PVCs: ten distinct chain types are currently present in Vietnam. PVC types 1-5 are the traditional and yet more common chains, while type 6 and type 7 are modern chains arranged by private companies; and type 9 and type 10 are incomplete chains as part of the chain is organized outside the country, and they are responsible for only a small proportion of pig production in the country. Similar to chicken and beef value chains, the PVCs in Vietnam are flexible due to the presence of traders in the chains (Nguyen et al. 2017). The amount of pork consumed in Vietnam is 2.5 and 5 times higher than the poultry and beef consumption (Nguyen and Ngo 2016). In contrast, the value of imported pork accounts for only $4 \%$ of the total value of imported meat, which is much lower than the value of imported poultry and beef with $51 \%$ and $45 \%$ (Nguyen and Ngo 2016). Although the proportion of imported pork is increasing after the outbreaks of African swine fever in 2019, the domestic PVCs remain the major pork suppliers in Vietnam.

In the domestic, complete PVCs (types 1 to 8), actors are linked in the chain of processes, necessary for the transformation and transportation of live pigs from the farms to pork, offal to consumers: raising pig, delivering live pig, slaughtering pigs, delivering carcasses, selling and processing pork. In the shorter chains, such as types $1-3$, more common in rural and highland areas, the actors often combine multiple activities in the chain (Hoa 2014; Unger et al. 2018). For example, slaughter men purchase pigs from farmers and slaughter only one or two pigs per day and sell all pork and products to consumers on the same day (Unger et al. 2018). In the longer chains, such as PVC types 4 and 5, common in urban areas, the actors can specialize in only one activity, in chain types 4 and 5 due to the high population and associated demand for pork and offal. More data are needed on the PVCs in the central and southern provinces of the country to generate and publish a comprehensive overview for the whole country and to support policy development in management and control of food safety.

Traceability of pork and pork products is a big challenge in the Vietnamese context due to the diversity of sources of pork and the complex PVCs, without adequate record keeping on pork origin. At the start of the chains, small-scale farms often do not keep records on pig parameters, e.g. age and occurrence of disease. The inclusion of middlemen, pig traders and pork traders in the PVCs complicates the process even further, as they gather pigs from different farms (Baudon et al. 2015), and they expand the PVCs over a large geographical area without recording pig origin (Thuan et al. 2000). Furthermore, retailers purchase carcasses and sell pork at the wet markets without noting pork origin (Chau et al. 2017). At the same time, linkages between actors in the PVCs are not well documented, and none or few official contracts exist between actors in the traditional PVCs; e.g. transactions between producers, middlemen, traders and slaughter men are almost entirely driven by verbal agreements (Costales and Catelo 2009; Tiongco et al. 2009; Tan and Hung 2013; Unger et al. 2018; Chau et al. 2017; Nga et al. 2017). Finally, a diversity of chain types can be present in the same region, e.g. ten different PVCs are present in Vinh-a city in Nghe An province - and in Hanoi and Ho Chi Minh City (Hoa 2014; World Bank 2017). Therefore, traceability of pork and pork products is not yet established in the Vietnamese setting, though the traceability is an important criterion for pork product quality/ safety (Madec et al. 2001).

Pork safety is a big concern in Vietnam, considering the number of people suffering from food-borne illnesses every year (Vietnam Ministry of Health and Health Partnership Group 2016), pork being the most popular type of meat in Vietnam (Nguyen et al. 2006) and the existence of certain culinary habits to consume raw or undercooked pork (DangXuan et al. 2015a, b; Ng-Nguyen et al. 2017). Several risks for pork safety were identified in the PVCs described in this study. No separate areas for processing internal organs and meat are available in the family slaughterhouses, and slaughtering is performed on a concrete floor (Yokozawa et al. 2016; Duong 2018). Carcasses are delivered using motorbikes to the market without being covered. In addition, pork is presented on wooden tables, unpackaged, which can lead to bacterial contamination of pork products (Yokozawa et al. 
2016; Dang-Xuan et al. 2019). Moreover, the Ban breed chain (type 8), in which pigs are left roaming freely to scavenge for feed is increasingly popular in Vietnam (Huong et al. 2009). Nonetheless, this chain possesses high risks for transmission of zoonotic diseases such as Taenia solium taeniosis/ cysticercosis and trichinellosis (Van De et al. 2015; NgNguyen et al. 2017). Vietnamese people have the habit of eating raw and undercooked pork, including fresh pig blood, increasing the risk of acquiring food-borne diseases (CarriqueMas and Bryant 2013; Huong et al. 2014). The transport of pig products can spread animal diseases such as African swine fever and foot and mouth disease, which have a big economic impact. Tackling these constraints of PVCs is vital to control and reduce the high incidence of pork-related health hazards both within and outside Vietnam.

There is a growing consumers' demand for accurate and timely traceability of products and activities in the pork supply chains (Opara 2003) and in the PVCs in particular. In Vietnam, modern PVCs such as types 6 and 7 have recently emerged. Private companies controlling a large part of the chain can assure a better traceability and supply of safe pork to consumers in cities as compared with the traditional PVCs and should, therefore, be encouraged. Furthermore, an improved management of traditional PVCs could be applied by a proper policy to ensure safe and nutritious foods and sustainable development.

Our study has one major limitation pertaining to the nature of retrieved records. Our search strategy was designed to retrieve as many relevant records as possible. We searched seven international as well as Vietnamese databases for relevant published records. Moreover, we consulted experts at the Vietnamese Department of Animal Health and the Vietnam University of Agriculture to gather additional grey data on the PVC. Nevertheless, a number of unpublished technical or consultancy reports discussing the PVCs in Vietnam might exist, which were not identified in the current study.

In conclusion, this systematic review is the first of its kind, summarizing the current knowledge on the pork value chain in a developing country, an essential step to assess pork traceability and food safety. The study has identified a diversity of PVCs in Vietnam, among which the most common PVC involves producers, slaughter men, retailers and consumers. In more complex chains, in cities or for export of pork, middlemen and traders also participate in the PVC. Our review shows that the PVC in Vietnam is not only limited to the Vietnamese territory, as PVCs start or end in other countries in Asia, Europe and America. Although industrial forms of PVCs are slowly developing, the traditional PVCs characterized by small-scale farming and lack of contracts and record keeping are still prevailing in the country. More attention should be given to adequate training for producers, middlemen and slaughter men considering the importance of record keeping for pork safety and traceability in Vietnam.
Acknowledgements The authors sincerely thank Dr. Fred Unger, Dang Xuan Sinh and Nguyen Thi Thinh of the International Livestock Research Institute (ILRI) for providing a report of the PVC mapping performed by ILRI and the Vietnam National Institute of Agriculture (VNUA) and recommendations for our study.

Funding information This work was supported by the Directorate General for Development (DGD), Belgium, through the individual $\mathrm{PhD}$ program (Man TT Nguyen) of the Institute of Tropical Medicine Antwerp, Belgium.

\section{Compliance with ethical standards}

Conflict of interest The authors declare that they have no conflict of interest.

\section{References}

Baudon, E., Fournié, G., Hiep, D.T., Pham, T.T.H., Duboz, R., Gély, M., Peyris, M.,Cowling, B.J., Ton, V.D. and Peyre M., 2015. Analysis of swine movements in a province in Northern Vietnam and application in the design of surveillance strategies for infectious diseases. Transboundary and Emerging Diseases, 64, 411-424.

Carrique-Mas, J.J. and Bryant, J.E., 2013. A review of foodborne bacterial and parasitic zoonoses in Vietnam. Ecohealth 10, 465-489.

Chau, L.T.M., Lebailly, P. and Trung, T.Q., 2017. Enhancing farmers' market power and income in the pig value chain; a case study in Bac Giang province, Vietnam. Livestock Research for Rural Development, 29, \#221.

Costales, A. and Catelo, M.A.O., 2009. Contract farming as an institution for integrating rural smallholders in markets for livestock products in developing countries: (II) Results in Case Countries. FAO - ProPoor Livestock Policy Initiative, Research report.

Dang-Xuan, S., Bryant, J. E., Unger, F., Ngo-Thanh, B., Ngoc, B. V. T., Pham-Duc, P., Grace, D., and Nguyen-Viet, H., 2015a. Risk pathways and prevalence in slaughtered pig blood of Streptococcus suis in Vietnam. Tropical Medicine and International Health, 20, 395.

Dang-Xuan, S., Nguyen-Viet, H., Pham-Duc, P., Tran-Thi, N., Thanh Nguyen, T., Unger, F., Makita, K and Grace, D. 2015b. Hygiene and microbial contamination along the pork value chain in Vietnam. Tropical Medicine and International Health, 20, 394.

Dang-Xuan, S., Nguyen-Viet, H., Pham-Duc, P., Unger, F., Tran-Thi, N., Grace, D., and Makita, K. 2019. Risk factors associated with Salmonella spp. prevalence along smallholder pig value chains in Vietnam. International Journal of Food Microbiology, 290, 105115.

Department of Agriculture and Forest., 2003. Báo cáo đẩy mạnh phát triển chăn nuôi lợn xuất khẩu ở 16 tỉnh phía Bắc góp phần chuyển dịch cơ cấu kinh tế nông thôn, thúc đẩy tiêu thụ sản phẩm thị lợn hàng hóa nhằm tăng thu nhập cho nông dân (in Vietnamese) http:// sti.vista.gov.vn/file DuLieu/dataTLKHCN//Vd1248-2005/2003/ Vd1248-20052003034.pdf. Accessed 18 Dec 2018.

Duong, T. T. Q., 2018. Characterization of Salmonella isolated from pig slaughterhouses and pork in market in Hanoi, Vietnam, (MSc thesis, Institute of Tropical Medicine).

FAOSTAT, 2019. http://www.fao.org/faostat/en/\#data/QA. Accessed 20 Feb 2019.

Hoa, N. T. M., 2014. Chuỗi cung thịt lợn trên địa bàn tỉnh Nghệ An (in Vietnamese). Journal of Agricultural and Rural Development, 1+2, $11-17$.

Hoang, T.H., 2012. Quyết định phê duyệt quy hoạch tổng thể phát triển sản xuất ngành nông nghiệp đến 2020 và tầm nhìn đến 2030 (in Vietnamese). http://www.chinhphu.vn/portal/page/portal/chinhphu/ 
noidungquyhoachnganh? docid=1582\&substract=\&strutsAction= ViewDetailActi. Accessed 14 Dec 2018.

Huong, L. N., 2012. Nghiên cứu ngành hàng lợn thịt trên địa bàn tỉnh Hưng Yên (in Vietnamese) ( $\mathrm{PhD}$ thesis, Vietnam University of Agriculture. p.189). http://luanan.nlv.gov.vn/luanan?a=d\&d= TTcFlGyItjlW2012.1.6. Accessed 1 December 2018.

Huong, P. T. M., Hau, N. Van, Kaufmann, B., Zárate, A. V., and Mergenthaler, M., 2009. Emerging supply chains of indigenous pork and their impacts on small-scale farmers in upland areas of Vietnam. International Association of Agricultural Economists Conference, Beijing, China.

Huong, V. T. L., Hoa, N. T., Horby, P., Bryant, J. E., Kinh, N. Van, Toan, T. K. and Wertheim, H. F. L., 2014. Raw pig blood consumption and potential risk for Streptococcus suis infection, Vietnam. Emerging Infectious Diseases, 20(11), 1895-1898.

Huyen, L.T. T, Muth, P. C., Markemann, A., Schöll, K., and Valle Zárate, A., 2016. Potential for the development of a marketing option for the specialty local Ban pork of a Thai ethnic smallholder cooperative group in Northwest Vietnam. Tropical Animal Health and Production, 48(2), 263-271.

Lapar, M. L. A., Toan, N. N., Que, N. N., Jabbar, M., Tisdell, C., and Staal, S., 2009. Market outlet choices in the context of changing demand for fresh meat: Implications for smallholder inclusion in pork supply chain in Vietnam. International Association of Agricultural Economists Conference, Beijing, China.

Lapar, M. L. A., Toan, N. N., Staal, S., Minot, N., Tisdell, C., Que, N. N., and Tuan, N. D. A., 2012. Smallholder competitiveness: insights from household pig production systems in Vietnam. International Association of Agricultural Economists Conference, Foz Do Iguaçu, Brazil. https://ageconsearch.umn.edu/record/126820. Accessed 18 Dec 2018.

Lemke, U., Kaufmann, B., Thuy, L. T., Emrich, K., and Valle Zárate, A., 2006. Evaluation of smallholder pig production systems in North Vietnam: Pig production management and pig performances. Livestock Science, 105(1-3), 229-243.

Madec, F., Geers, R., Vesseur, P. C., Kjeldsen, N., and Blaha, T., 2001. Traceability in the pig production chain. Revue Scientifique et Technique de l'OIE, 20(2), 523-537.

Moher, D., Liberati, A., Tetzlaff, J., and Altman, D. G., 2009. Preferred reporting items for systematic reviews and meta-analyses: the PRISMA statement. PLoS Medicine. 6(7), e1000097.

Nga, N. T. D., 2016. Úng xử của hộ gia đình trong tiêu dùng thịt lợn tại tỉnh Hưng Yên (in Vietnamese). Journal of Economics and Development, 229(2), 29-36.

Nga, N. T. D., Ninh, H. N., Hung, P. Van, and Lapar, M. L., 2014. Smallholder pig value chain development in Vietnam: Situation analysis and trends. Project report to International Livestock Research Institute (ILRI), Nairobi, Kenya. https://cgspace.cgiar. org/bitstream/handle/10568/53935/pr_situation_analysis_vietnam web.pdf?sequence=7. Accessed 18 Dec 2018

Nga, N. T. D., Lapar, M. L., Hung, P. Van, Long, T. Van, My, P. K., Toan, P. T. and Unger, F., 2017. An evaluation of economic viability of small scale slaughterhouses in Vietnam: Implication for pig value chain development. The 9th ASAE International Conference: Transformation in Agricultural and Food Economy in Asia 11-13 January 2017 Bangkok, Thailand, 813-828.

Ng-Nguyen, D., Stevenson, M. A., and Traub, R. J., 2017. A systematic review of taeniasis, cysticercosis and trichinellosis in Vietnam. Parasites and Vectors, 10(1), 1-15.

Nguyen, D., and Ngo, K., 2016. Meat market in Vietnam. Ipsos business consulting. https://www.ipsos.com/sites/default/files/2016-08/meatmarket-in-vietnam.pdf. Accessed 28 Nov 2018.

Nguyen, T. M., Yutaka, T., Fukuda, S., and Kai, S., 2006. The pork consumption and distribution in urban areas of Vietnam before WTO accession. Journal of the Faculty of Agriculture, Kyushu University, 51(2), 459-466.
Nguyen, T. T. T., Fearnley, L., Dinh, X. T., Anh Tran, T. T., Tran, T. T., Nguyen, V. T., Tago, D., Padungtod, P., Newman, S.H. and Tripodi, A., 2017. A stakeholder survey on live bird market closures policy for controlling highly pathogenic avian influenza in Vietnam. Frontiers in Veterinary Science, 4, 136.

OEDC (Organisation for Economic Co-operation and Development), 2018. Meat consumption. https://data.oecd.org/agroutput/meatconsumption.htm. Accessed 28 Nov 2018.

Opara, L., 2003. Traceability in agriculture and food supply chain: a review of basic concepts, technological implications, and future prospects. Journal of Food Agriculture and Environment, 1, 101-106.

Peters, D., Tinh, N. T., Hoan, M. T., Yen, N. T., Thach, P. N., and Fuglie, K., 2005. Rural income generation through improving crop-based pig production systems in Vietnam: Diagnostics, interventions, and dissemination. Agriculture and Human Values, 22(1), 73-85.

Schöll, K., Markemann, A., Megersa, B., Birner, R., and Zárate, A. V., 2016. Impact of projects initiating group marketing of smallholder farmers-A case study of pig producer marketing groups in Vietnam. Journal of Co-Operative Organization and Management, 4(1), 31 41.

Tan, P. T., and Hung, P. V., 2013. Nghiên cứu các tác nhân tham gia kênh tiêu thụ sản phẩm thịt lợn trên địa bàn tỉnh Nghệ An (in Vietnamese). Journal of Science and Development, 11(5), 767-776.

Thuan, N. T., Kai, S., and Yutaka, T., 2000. An overview on pig production and pork market in the Red River Delta in Vietnam. Journal of the Faculty of Agriculture, Kyushu University, 45(1), 325-334.

Tiongco, M., Lapar, M. L., Costales, A., Son, N. T., Jabbar, M., and Staal, S., 2009. Is contract farming really pro-poor? Empirical evidence from Northern Vietnam. International Association of Agricultural Economists Conference, Beijing, China.

Tu, P. K., Hoang, N. D., Le Due, N., Hendriks, W. H., and Verstegen, M. W. A., 2010. Nutritional constraints and possibilities for pig production on smallholders' farms in Central Vietnam. Asian-Australasian Journal of Animal Sciences, 23(2), 253-262.

Unger, F., Grace, D., Nguyen-Viet, H., Pham, V.H., Pham, D.P. and Lapar, L., 2018. Reducing disease risks in smallholder pig value chains in Vietnam. ACIAR, Canberra, Australia. https://www. aciar.gov.au/sites/default/files/project-page-docs/final report lps. 2010.047.pdf. Accessed 23 Dec 2018.

De, N. Van, Nga, V. T., Dorny, P., Trung, N. V., Minh, P. N., Dung, D. T., and Pozio, E., 2015. Trichinellosis in Vietnam. The American Journal of Tropical Medicine and Hygiene., 92(6), 1265-1270.

Vietnam Livestock Production, 2018. Tình hình chăn nuôi cả nước năm 2018 (in Vietnamese). https://channuoivietnam.com/tinh-hinhchan-nuoi-ca-nuoc-nam-2018/. Accessed 20 Feb 2019.

Vietnam Ministry of Health and Health Partnership Group., 2016. Joint Annual Health Review 2015: Strengthening primary health care at the grassroots toward universal health coverage, (Medical Publishing House, Hanoi, Vietnam)

World Bank, 2017. Vietnam food safety risks management: challenges and opportunities: technical working paper (English). http:// documents.worldbank.org/curated/en/415551490718806138/pdf/ 113828-REVISED-WP-Technical-working-paper-EN-FINAL.pdf. Accessed 28 Nov 2018.

Yokozawa, T., 2014. A study of Salmonella prevalence in pork value chain from pig slaughterhouses to markets in Hung Yen, Vietnam. (BSc thesis in Veterinary Science, Hokkaido, Japan: Rakuno Gakuen University).

Yokozawa, T., Dang-Xuan, S., Nguyen-Viet, H., Lapar, L. and Makita, K., 2016. Transition of Salmonella prevalence in pork value chain from pig slaughterhouses to markets in Hung Yen, Vietnam. Journal of Veterinary Epidemiology, 20(1), 51-58.

Publisher's note Springer Nature remains neutral with regard to jurisdictional claims in published maps and institutional affiliations. 